\title{
The local South African worshipping community as a site for spiritual formation towards transformation
}

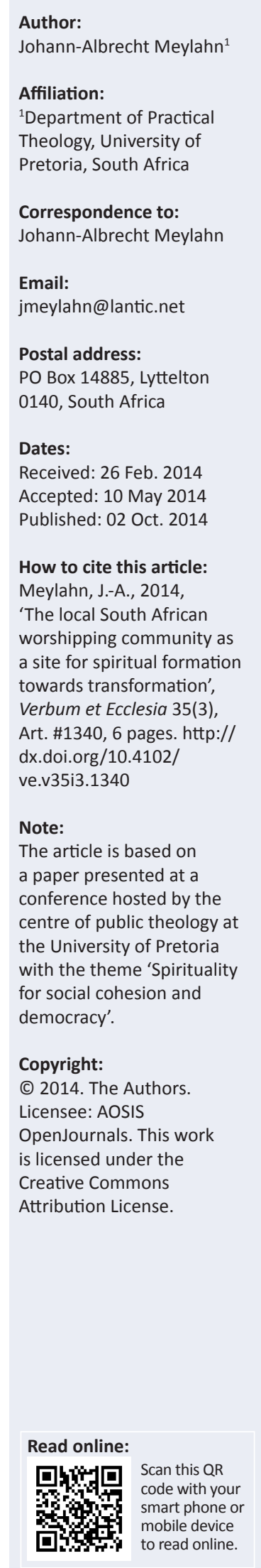

The article focuses on the local worshipping community as a site for the spiritual formation of citizens to become agents of transformation in public life. How are citizens spiritually formed so that, through their witness and praxis, they become instruments of transformation, thereby challenging the dominant discourses by offering, through their collective witness and praxis, redeeming alternatives? To answer this question, the article focuses not on a methodology but rather offers suggestions as to how to nurture a radical spirituality towards the formation of agents of transformation. The specific South African context with its numerous socioeconomic and political challenges as well as the plurality of voices and values need to be taken into consideration. Therefore the challenge is to develop an inclusive spirituality.

\section{Introduction}

The article is based on a paper presented at a conference hosted by the centre of public theology at the University of Pretoria with the theme 'Spirituality for social cohesion and democracy'. It is a daunting prospect to write on such a challenging theme as social cohesion and democracy, as each of these terms - public theology, spirituality, social cohesion and democracy - are contested by the plurality of meanings harboured in these terms. Furthermore, they are haunted by future meanings seeking to come to these terms. Because of the plurality of conflicting meanings, any interpretation on any of these key terms immediately positions the speaker. Taking into consideration the context of the speaker and the fact that labelling or categorisation is part and parcel of this context, it is inevitable: you stand categorised and labelled. I am not complaining as I was reading with the same labelling, categorising the other papers because that is what one does, believing that this is how one gets a 'grip' on reality. One gets a grip on reality by labelling, naming, classifying and categorising, and these classifications are institutionalised and legitimised by authorities (the names of authors quoted and referenced) and then reified through interpreted experiences that are offered as proofs. Yet, it is not a grip on reality that one gets but rather the proverbial, what one deserves, as it is the reality that one's language composed, thereby creating both the subjects of that specific linguistic chain of referents as well as all the different classified and categorised objects.

The spirituality that I am seeking - maybe because of my context, the history of which so readily classified and categorised people and the future of which still seems to be haunted by that same desire to classify and categorise, is to move beyond such classification and categorisations. In moving beyond such classifications and categorisations there is a move towards social cohesion and democracy, that is, if such things are possible. Thus, I shall not seek to offer a definition of public theology, spirituality, social cohesion and democracy. As some might say, I shall play it safe by playing with the various meanings harboured in these terms which are capitalised so differently in different language games. I might be accused of sitting on the fence by not committing to any particular interpretation of these terms. This would, on the one hand, not be an incorrect label as, yes, I might be playing it safe. The reason for playing it safe is that I have no intention of getting involved in the war of meanings where each of the warring factions has good reasons, values, proofs (maybe) and means to argue for their particular veridiction and thus offer felicitous speech on the theme of democracy, social cohesion and spirituality. On the other hand, fence-sitting would also be an incorrect label because, although my allegiance is not to any of the current disputing factions, my allegiance is to the meanings still to come. There is a messianic expectancy created by future meanings that haunts these terms but without any clue as to what those future meanings might entail. In my messianic expectation, with or without a particular messiah, I am inspired by the potential future meanings of these key terms, but I am not guided by such future meanings as I have no clue as to what they might be. Therefore, I am rather guided by the victims and survivors of past and present meanings. In other words, I am guided to dance this dance of meaning with a certain bias, to dance particularly with those who have been excluded from the dance floor as their meanings and understandings of these noble terms were deemed inappropriate by some or other power group that gave itself the authority 
to determine the norms by which to judge and decide who is acceptable and therefore invited to the dance floor and who is unacceptable and therefore refused. Although there is a particular bias in listening to the excluded, their particularity or the particular meanings they give to these terms is not the new Meaning or the new Truth but just one more meaning with its own means, values and proofs for veridiction. Thus, they have their own felicitous and infelicitous speech. I am not their spokesperson. What arrogance to even seek to offer felicitous speech in the name of someone else. Thus, there is no particular group in whose name I seek to speak, but if I must speak in a name, and in a name I must speak, then in the name of a fragile universal truth: that in all speech there are always exclusions and marginalisation and therefore all speech is cracked, broken language as in Marianne Faithfull's beautiful song 'broken English'.

\section{Broken English}

That is all I can offer: broken English or broken, wounded language. This wounded language, wounded text, I offer as a kind of spirituality or perhaps even a kind of public theology. Thus, playing it utterly unsafe as I do not know of what I speak, I do not have the protection of great institutions nor am I licensed or legitimised to speak in the name of indisputable authors. I also do not have the backing of megabytes of empirically collected data of experiences to reify my findings, and I do not have a majority or minority on my side in whose name I speak. All I offer is my broken English. Without trying to hide its brokenness with powerful institutions or powerful anti-institutions with their respective legitimising names and reifying majority of minority experiences, I offer you wounds - a broken body of language, English in this particular case. I am sharing this with you as if gathered around the Eucharist table. I offer this broken language as a spirituality or theology for the agora.

In what follows, I might drop a name or two, authoritative names maybe for some. Am I thereby lending legitimacy to what I say? Maybe, or maybe I mention these names as a cloud of witnesses as I witness and testify of a faith and a hope that comes with broken language, journeying towards offering a spirituality of a worshipping faith community yearning for transformations or reformations:

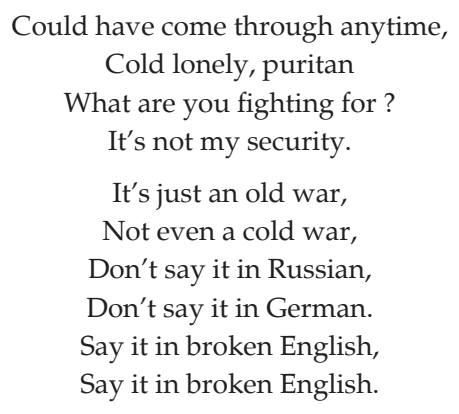

Marianne Faithfull's (1979) 'Broken English' will guide this section as it perhaps captures something of the battle that wages in capitalised terms just as the battle that waged in Europe or the West during the cold-war years. There is a war that wages in terms like democracy, social cohesion, spirituality and public theology as one can say these capitalised names or nouns in neo-liberal language, in postcolonial language, black theological language, contextual theological language and many other languages. Faithfull's plea, in a voice characterised by a struggle on the streets of drug addiction, is: Do not say it in these powerful languages, but say it in a broken language. Why?:

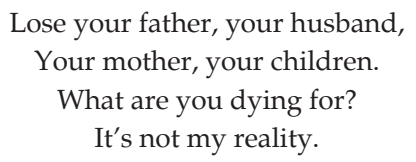

Because there have been so many casualties in the name of these powerful Names, Names that thought that they had captured the essence by capitalising these terms in their language. What are they dying for? It is not my security, it is not my reality! Maybe, Faithfull should rather have said: it is not reality. But it is! It is exactly that: my, your, their reality! If she argued that it is not the Reality, it would have made sense in the sense that none of these languages captures the Reality of democracy or social cohesion completely and absolutely, but together they would maybe come closer to the truth of these terms. In that sense, it would make sense to speak of a broken language as each individual language is limited, and because of their limitations, one needs the different languages. If that was the case, one could have come up with a proposition that only together, in transversal or inter-lingual conversations, these different languages could bring one closer to the essence or the Reality of democracy and social cohesion. Thus, one would again be creating a duality between the pure essence (Reality) of these terms, one could say the infinity of these terms, and then humbly realising the finiteness of our languages and their inability to capture the greatness of these noble ideas. In that sense, one could speak of broken language, seeking to get a grip on ideas that cannot be captured by single languages. Such an interpretation would be highly democratic and offer a way towards social cohesion, and therefore, it could be understood as a spirituality of humility and dependence on the other languages. A noble thought indeed, but that is not the road I seek to travel in this article.

Marianne Faithfull does not argue in her song that it is not the Reality, but she says that it is not my reality, and because it is not $m y$ reality, she pleads for broken English.

She is not arguing that Russian, German or English does not by themselves capture the essence of reality, and therefore we need to dream of a time when the different languages realise their lack and seek to speak in harmony to get closer to the Reality. She is not arguing that we need a harmonious symphony of various languages to approach elusive Reality. What would be the point of that? It would be replacing differing powerful languages with one megapowerful language, or, one could maybe argue, a globalmeta-language. Maybe that is what we currently have in the so-called (so-named) global village. 
She is crying, weeping, as she says that what you are talking about is not my reality, and yet it is determining my reality as it is taking from me my family. Therefore, these powerful languages are excluding her and her reality whilst determining so much of her day-to-day experiences and forcing her to interpret her experiences in their languages. One is forced to interpret the experiences of democracy or the experiences of the lack of democracy in neo-liberal or postcolonial terms. She is knocking on a locked door with her broken English, which has excluded her and her reality. She is pleading for broken English, pleading for a language that is not so absolute and exclusive but has room for her reality.

She does not want the doors to be flung open so that she can have the dance floor all to herself where her reality wins the dance or the day. No, what would be the point of that? That would just replace one language with another language, which has happened so often in the history of revolutions where one language replaced another without anything really changing, except for who is included and who is excluded.

There is always a song pleading for broken English at every conference, symposium, in every institution and in every epoch of history! Not because our languages miss the target, for what target would they be missing - the one they created in the first place? The solution is not to seek to speak more inclusively or democratically to one another in order to argue that the more one is socially cohesive or inclusive, the closer one gets, together with others, to the elusive target or Reality. No, languages individually or in harmonious democratic and socially cohesive transversal togetherness remain exactly what they are individually: composed. Because they are composed, they will always exclude, and therefore, there will always be somebody pleading: This is not my reality, not my security, please speak broken English! Thus, social cohesion and democracy are always of the future coming towards one, calling, beckoning and thus haunting whatever is currently understood and interpreted as democracy, social cohesion. These terms are haunted by these voices, begging for broken language. A broken language is a language that creates room for hospitality and allows itself to be broken even more by what it welcomes. It does not seek to be pure and exclusive.

This has nothing to do with the gap between language and reality, thought and things, or the gap between human rationality and the Ding-an-sich. It has nothing to do with the duality: language and world, thought and reality, subject and object. It does have to do with the worlds or realities we live in. It has to do with the habits and habitats that are created by our language. Each of these worlds or habitats or realities has its own thoughts and reality, subjects and objects, language and world and therefore its own habits. Language is the house of Being. ${ }^{1}$ It is not the tool that one uses to access reality, it is not the tool one uses to socially construct reality, it is the house of Dasein: as such it includes the thinking (constructing) subjects as well as the things thought. It is what creates both subjects and objects, thoughts and things thought. Therefore, bringing more languages to the table does not bring one closer to the truth or Reality. The multi-lingual transversal, inter-disciplinary does not bring anyone closer to Reality or Truth, but it creates a new language and world, maybe a global village, where the values of democracy, inclusiveness and social cohesion are high on the priority list, interpreted in the language that best serves the security and the subsistence of the powerful in the global village. Together with the composition of such a global village, there will however be somebody weeping, pleading: Do not speak democracy, social cohesion. Speak broken languages as this is not my reality.

I am not making a value judgement on democracy and social cohesion as I could have chosen any other value of a specific language game. What I am trying to come to terms with, to come to language with, is exactly that: to come to language, yet whilst in language, and discover the grammar of that which I cannot escape and of which I am part. Is it possible to discover the grammar of that in which one is and through which one discovers whatever one discovers? One comes to language with language, and one cannot escape those language worlds, habitats, spheres. ${ }^{2}$

\section{Public theology as worshipping community for spiritual formation and transformation}

It is always daunting to use the term public theology or even just the term theology - the logos of God, where logy can be understood in so many different ways just as God is interpreted in so many different religions and even nonreligions. There is a battle that rages in the word or name 'God'. It is a battle between various religions, various forms of theism and between theism and atheism. I do not want to get involved in that holy war just as I did not want to get involved in the warring meanings harboured in the terms like democracy. I would rather focus very literally (in language and through language) on the word (logos) of theos (God), not the science (logos) or theory of God but just the word 'God' and in that sense offer a theology for the agora: a public theology.

Derrida (1995:56) believes that the word 'God' can be saved and thereby also save God, if that word is understood as the infinite desertification of language. Language deserts us infinitely like the sand in the desert. It cannot be used to come to terms, to name, understand, comprehend with the wholly Other, but as Derrida says, that is also true for every other (tout autre est tout ature, Derrida 1995:76). Therefore, language deserts us, but it is all we have. It is a pharmakon (Derrida 1981:99) - both remedy as it creates a world and poison as the created world is a textual world, fictional if you like, and thus deserts us with regards to Reality. Reality runs through the fingers of language like the fine desert sand and cannot be captured.

2.See Peter Sloterdijk's (2011) trilogy on spheres, specifically the first volume, Bubbles. 
Or as Latour argues, the two modes of representation and re-production are often confused, and because of this confusion, we end up in the subject and object vise '... and we would have to believe in the existence of an "external material world known by the human mind"' (Latour 2013:124). One can take something like democracy as an example: there is a whole network of things that need to be in place for a 'real' democracy to exist, and many of those things that are in place in real existing democracies have absolutely nothing to do with democracy, yet we still refer to it as democracy. For democracy to exist as such, it needs to subsist, and to subsist, it needs a whole network of things - political, economic, social, cultural, demographic, et cetera. Between all these things there are numerous discontinuities. Yet, some value or means allows the discontinuities to be bridged so as to produce itself again and again as democracy so that it can be presented as democracy. In this re-production of democracy, this network of discontinuities is not taken into account and each of the actors that 'make democracy possible' is, in turn, made up of a whole network of discontinuities. The representation of democracy is also only possible by leaping over traces and traces of discontinuities that are bridged by some means or value. I here refer to the kind of discontinuities or traces that Derrida (1982:11ff.) speaks of, that characterise representation in language.

In the previous section, I tried to come to terms, come to language from within language, by trying to understand or rather describe the grammar of language as the house of Being. If God is a good name to save for this grammar of language, which is the house of our Being, then one is in God and God is certainly omnipresent and omniscience. Now, the story of Christ tells the story of this God or, according to the Gospel of John, this word of God (theology) became flesh. The Word became flesh, became reality. The Word became world or into the world. This sounds like an exemplary narrative for what was discussed above: the grammar of language. What if this story is not the telling of a metaphysical truth? What if this story is exactly that: the creation of the creation of what if? What if it is the metaphor of metaphor, not the truth of metaphor or the truth beyond metaphor but the grammar of metaphor as metaphor? Language creates text, word that becomes composes, creates, poiesis realities. It is as if the story of Christ is perhaps the story of language, and as the story of language, it is perhaps the story of worlds or realities. I invite you to go along with this trajectory. What kind of habit could the story of Christ instil with regards to both the grammar of language and Christians, as his followers or disciples, living in these worlds but called to be in but not of these worlds? Of what are Christians if Christians are not a creation of the dominant languages that they use in their daily lives? Are they the creation of another language? Or are they those who gather around the table of broken language, receiving the broken word through broken word and sacrament? What else are they then - redeemed sinners worshipping together? Redeemed of their language-world and yet inescapably created by their language worlds. As such, they are always sinners, simul justus et peccator, always justified and sinners at the same time.
There might be those who will accuse me of playing with words, and I would be inclined to respond: Could I play with words, could I be their master? To do that, I would have to be beyond words in a transcendent place from where I could control, manipulate and play with the words as if they were tools at my disposal. Could it not be, perhaps, that words play with me, and I am their creation and they my master? Or maybe all there is is a play with words or a word-play, a drama, a narrative that creates subjects within a world, who are in turn created in the image of that creative word and who therefore in their turn create words and worlds.

How does one respond by such playful playing of words? One would need to arrest this disruptive play, keep these playing unserious children away from the master and teacher of truth. And yet the way, the truth and the life responds and says: let the children come to me, for theirs is the kingdom of God (Mt 19:14).

My 'natural' desire is to arrest the play, to discipline the child. To discipline the child in the name of the Father, in the name of the law (nomos) in true Lacanian style. That is exactly what they did to Christ: they arrested the disruptive one who played with children, prostitutes and all the other outcasts who were not invited to dine at the exclusive table of the King. They did it in the name of the seriousness of the law and in all seriousness crucified him in the name of the law of God and Emperor because he threatened their security. This one associated with the outcasts, those who had no place in the orderly kingdom that has ontologically been categorised into what is and what should not or cannot be. He associated and gathered around him those who should not be, who had no place in a world controlled by and conformed to the law of the dominant language game. For that, he was crucified as the ultimate criminal because he threatened the stability and sanity of their world. And yet, the followers of this crucified one believe that he rose again on the third day. A testimony, of course, most unreliable, as it was women who were the first witnesses, and who could possibly take them seriously?

This whole faith is foolishness to those seeking logic, philosophy and a world clearly and securely controlled by laws and norms. It is also a stumbling block to those seeking certain and secure signs that do not play but conform and, more importantly, represent what truly is. Thus it is a faith, a spirituality that is childish foolery, asking questions about things that grown-ups have long ago established as certain and true, right and wrong, things about which grown-ups have clearly established and institutionalised the laws and norms that go with that certainty. Faith is a stumbling block to a certainty about what is and is not, what is right and wrong, truth and lie, story and fact, and the list of dualisms goes on in the world of the un-foolish grown-ups.

Yet, this childish foolery is rather persistent as it comes again and again from the margins of all our certainties, questioning and opening them for what is to come. And there, from the margins, as the norms and laws seek to crucify it, it or they crucify the dominant language games and dominant language 
worlds with their persistent deconstructing questions or deconstructing non-being (or not-supposed-to-be). It is a crucifixion, questioning or deconstruction with a request: speak broken English because your worlds and games are not my world and game. It is knocking on the doors of all secure and serious institutions of knowledge and truth that have the renowned ability to classify, categorise and label and thereby give ontological status to all that is and that is not within a given world. These institutions of knowledge are legitimised by the names of the great fathers and founders of the sciences and reified again and again by long traditions of (interpreted) experience. In the name of these fathers and founders of worlds and language games, in the name of the law, these children are told to grow up and leave their childish ways and accept and conform to the no, the law (nomos) of the father or else get out. Yet, he came to show us a different father. A father in whose house there are many rooms, a father in whose kingdom children can play, a father in whose house the prodigal son is given the ring of inheritance, a father in whose house the outcasts are invited and given place at the head of the table. He shows us a father on whose farm weeding is not allowed as there is no knowledge of good and evil institutionalised, legitimised and reified. No wonder Karl Barth ${ }^{3}$ said that the kingdom to come will bring all our knowledge to naught.

It is in the name of that Father, revealed by his only begotten Son, that I worship Sunday after Sunday a broken Word made flesh. I worship a broken crucified body, waiting to hear a broken crucified word that can only be received through grace and faith alone. ${ }^{4}$ I worship a word disrupted not by Reality or Truth but disrupted by love for the enemy or those excluded. I worship a word disrupted by a love for those crying and weeping, pleading with me not to speak my certain and secure language but pleading to speak a broken language of mercy because my secure certain and absolute language creates a world or a game that excludes. My secure and certain language, institutionalised, legitimised and reified, creates a certain secure world that has no room for the word of God made flesh, as the Christmas story tells on every Christmas Eve to the children who must eventually grow up.

That word that has no room in my world, that word that gathers to it all others that have no room, I seek to worship,

3.God is not hidden to us; He is revealed. But what and how we shall be in Christ, and what and how the World will be in Christ at the end of God's road, at the breaking in of redemption and completion, that is not revealed to us; that is hidden. Let us be honest: we do not know what we are saying when we speak of Jesus Christ's
coming again in judgement, and of the resurrection of the dead, of eternal life and coming again in judgement, and of the resurrection of the dead, of eternal life and eternal death. That with all these there will be bound up a piercing revelation - a
seeing, compared to which all our present vision will have been blindness - is too seeing, compared to which all our present vision will have been blindness - is too
often testified in Scripture for us to feel we ought to prepare ourselves for it. For we do not know what will be revealed when the last covering is removed from our eyes, from all eyes: how we shall behold one another and what we shall be to one another - men of today and men of the past centuries and millennia, ancestors and descendants, husbands and wives, wise and foolish, oppressors and oppressed traitors and betrayed, murderers and murdered, West and East, Germans and others, Christians, Jews, and heathen, orthodox and heretics, Catholics and Protestants, Lutherans and Reformed; upon what divisions and unions, what confrontations and cross-connections the seals of all books will be opened; how much will only then appear great and important; for what surprises of all kinds we much will only then appear great and important; for what surprises of all kinds we must prepare ourselves. We also do not know what nature, as the cosmos in which the sea, the broad valleys and heights, which we see and know now, will say and the sea, the broad valleys and heig then' (Barth 2003:45-46).

4.For further exploration of public theology as liturgical space where the sacraments play an important role in shaping people, see Smit (2003). knowing full well that I cannot as it is a disruptive word - knowing that I shall need to crucify it as it is a terrorist word threatening the homeland security of my world. Yet, that disruptive terrorist word died for me and my world that legally (in accordance with the law) crucified it. It died for my sin. It died for my relentless sin of not only creating a God but also a world in my image, believing myself master of my words and world and thereby also master of others, judging them and condemning them to neat heaps of corn and weeds. He died so that I, through faith and grace alone, could speak broken English and gather around a table to receive broken language, broken word made flesh, thereby including a wretch like me in the democratic and social cohesive kingdom always still to come where there is neither Jew or Greek, slave or free, man or woman.

A local community that worships such broken language and receives such broken language as a gift can become a site where citizens are spiritually formed or continually reformed through their witness and praxis of receiving broken language to become agents of transformation. They can become agents, not in the sense of acting in the name of $a$ or even the Truth or in the name of a particular world or language game, but in the name of the word that had no home, no place to lay its head in our worlds. The local worshipping community is a confessional community (see Smit 2008) that does not confess a particular language or world but confesses the story of a word. They confess the story of a word made flesh, who found no home, a light in the darkness that was not understood. They confess a word made flesh and crucified, a word crucified and resurrected, a broken word given to all as forgiveness for sins.

If such a broken word is worshiped and received through grace and faith alone and if that story is confessed Sunday after Sunday, that story creates a community with a particular spirituality of broken language. It creates a community where believers receive broken language, allowing their language worlds to be opened by love and hospitality offered to the stranger who pleads: Speak broken English for your world is not my world. These confessing and worshipping communities become communities of transformation or should I rather say reformation as there is always room for one more reality. They are communities haunted by the spectre of democracy still to come, haunted by the spectre of social cohesion still to come, and the way they deal with that haunting is to receive as gift: broken English, a broken, crucified word made flesh through broken word and sacrament.

\section{Acknowledgements Competing interests}

The author declares that he has no financial or personal relationship(s) that may have inappropriately influenced him in writing this article.

5.See Koopman's (2008) article on the vulnerable church. 


\section{References}

Barth, K., 2003, God here and now, Routledge, New York.

Derrida, J., 1981, 'Plato's pharmacy', in Dissemination, transl. B. Johnson, pp. 67-186, University of Chicago Press, Chicago.

Derrida, J., 1982, 'Différance', in Margins of philiosophy, transl A. Bass, pp. 1-27, Harvester, Brighton.

Derrida, J., 1995, 'Sauf le nom', in J. Derrida \& T. Dutoit (eds.), On the name, transl. D. Wood, J.J.' Leavey \& I. McLeod, pp. 35-88, Stanford University Press, Stanford.

Faithfull, M., 1979, 'Broken English', from the album Broken English, LP, Island, Matrix Studios, Producer Mark Miller Mundy, track \#1.

Heidegger, M., 1971, Poetry, language, thought, transl. A. Hofstadter, Harper \& Row, New York.
Koopman, N., 2008, 'Vulnerable Church in a vulnerable world?: Towards an ecclesiology of vulnerability', Journal of Reformed Theology 2, 240-254. http:// dx.doi.org/10.1163/156973108X333731

Latour, B., 2013, An inquiry into modes of existence: An anthropology of the moderns, transl. C Porter, Harvard University Press, London.

Sloterdijk, P., 2011, Bubbles: Spheres 1 microsphereology, transl. W Hoban, Semiotext(e), Los Angeles, CA

Smit, D.J., 2003, 'Living Unity?: On the ecumenical movement and globalization', Scriptura: International Journal of Bible, Religion and Theology in Southern Africa, 192-209. http://hdl.handle.net/10019.1/77353

Smit, D.J., 2008, 'Challenges for reformed churches in Africa: A contemporary narrative', International Journal for the Study of the Christian Church 8(4), 319336. http://dx.doi.org/10.1080/14742250802347018 